\title{
Walking Contemporary Indigenous Songlines as Public Pedagogies of Country
}

\author{
Margaret Somerville ${ }^{1}$ with Leanne Tobin ${ }^{2}$ and Jacinta Tobin ${ }^{3}$ \\ ${ }^{1}$ Western Sydney University, Sydney, Australia; ${ }^{2}$ Darug artist and singer/songwriter; and \\ ${ }^{3}$ Darug language teacher, musician and singer/songwriter
}

\begin{abstract}
The singing and dancing of Darug peoples once echoed throughout the Hawkesbury Nepean riverlands in ceremony. A long and challenging walk through bushland along the Nepean River, from Emu Green to Yarramundi on the Hawkesbury River, invites the walker to meditate on the presences and absences of these river places. Yarramundi is an important site for Darug people today, as it holds the history and cultural memories of singing the rivers in song and ceremony. Walking contemporary Indigenous songlines asks how we can come to know the river through walking the contemporary songlines of Darug songwriters and artists that sing the country of the riverlands today, and what is produced when this is enacted as public pedagogy. The paper explores a process of walking the Nepean River Trail, from my home at Emu Green to the Shaws Creek and Yellomundee Aboriginal cultural trails. The walk is reproduced as public pedagogy with collaborators Leanne and Jacinta Tobin, who have deep family connections to Yarramundi: connections that were temporarily lost through their early lives, and recreated through art, language and music practices in contemporary creations of ancestral songlines and connections. The public pedagogy performance was enacted at the Circular Quay International Passenger Terminal in a presentation of three songs, 73 artworks, and a short explanatory talk to an audience of 700 members of the Australian Institute of Landscape Architects. This paper asks: What does this public pedagogy produce? What does it mean to enact it at this historic site of colonial invasion and contemporary arrival of both temporary and permanent immigrants to this landscape?
\end{abstract}

\section{Keywords}

Indigenous song lines; deep time; singing painting river 


\section{Section 1: Walking the River's Songlines}

\section{Introduction}

The singing and dancing of Darug peoples once echoed throughout the Hawkesbury Nepean riverlands in ceremony. A long and challenging walk through bushland along the Nepean River, from Emu Green to Yarramundi on the Hawkesbury River, invites the walker to meditate on the presences and absences of these river places. Yarramundi is an important site for Darug people today, as it holds the history and cultural memories of singing the rivers in song and ceremony. Walking contemporary Indigenous songlines asks how we can come to know the river through walking the contemporary songlines of Darug songwriters and artists who sing the country of the riverlands today, and what is produced when this is enacted as public pedagogy. The paper takes as its starting point the provocation that walking methodologies are epistemological, ontological, and ethico-political orientations to how one engages with knowledge making (Springgay \& Truman, 2018). It explores these possibilities in relation to a long and arduous walk along the Nepean River from my home at Emu Green to Yarramundi (Yellomundee), once a place of song and ceremony, and later of early encounters between Aboriginali traditional custodians and newly arrived European settlers. In the paper, I employ creative arts and 'curious practice' (Haraway, 2015) to explore a collaboration with contemporary Darug artists and songwriters Leanne and Jacinta Tobin in relation to alternative ways of thinking and being in river Country.

The paper is divided into two sections. In the first section, I take up Juanita Sundberg's (2014) strategy of walking-with as decolonizing research that enacts situated and contingent ontologies between land, peoples and nonhuman others. I walk-with alone, as a meditative practice of becoming embodied in Country and the echoes of its historic and ancient past. In returning to the walk's representations, I dwell in the images and body memories to find their emergent possibilities for alternative onto-epistemologies of river Country.

In the second section, Leanne, Jacinta and I perform the singing painting river as a public pedagogy of walking at the very first site of contact, Sydney Cove, now the ferry passenger terminal at Circular Quay. We present the three songs, an extract of the oral presentation, and one of the 73 paintings that were displayed, wall sized, at the passenger terminal. This section asks: What does it mean to represent the singing painting river as public pedagogy in this most significant site of first contact?

\section{Representation and curious practice}

In her 'curious practice,' Vinciane Despret "thinks-with other beings, human and not ... a rare and precious vocation. Vocation: calling, calling with, called by, calling as if the world mattered, calling out, going too far, going visiting" (Haraway, 2015, p. 5). Every day I go visiting with Despret's curious practice, walking by the nearby Nepean River, part of the river system that encircles Sydney.

How can I capture the riverlands for you

smell of wild fennel in sun after rain

tinkle of bellbirds

rise and fall of cicada call

clip clop of gumboots through

wet of last night's dew

walking to river's edge's familiar dank breath

seeps into mine as I settle

against large sandstone rock 
overlooking deep part of river

light breeze riffles olive green surface

as water catches sparkles of sunlight.

Every moment in the riverlands is different: there're seasons, weather, time of day, sounds, smells, movements, skin touch, vibrations, light, air, waterflow, and the ways that all of the river's creatures respond to its ever-changing ecological sensorium. River texts slip out just as they emerge, images in the process of formation, but language falters in the face of riverland's proliferations. It is like trying to hold flowing water still; moving against the inevitable flow of the river's desirelines. This time, I take a very different walk, with the spirits of Darug artists and singer songwriters Leanne and Jacinta.

\section{Leanne and Jacinta}

I have known Leanne and Jacinta Tobin since I curated an art exhibition Meeting of the Waters (Somerville \& Power, 2016) for the Summer Institute of the Antipodes, where Leanne exhibited her artworks and Jacinta welcomed the international audience to Darug Country in language and song.

Leanne and Jacinta introduce themselves as descended from the Boorobrerongal and Wumali clans of the Darug peoples, the traditional Aboriginal people of the greater Sydney region. Maria Lock was their great, great, great grandmother and daughter of Yarramundi, a Karadji Elder of the Hawkesbury River. Maria is the intimate family connection to the place of Yarramundi in my long walk, the originator of the new songline, and memorialised in Leanne's artworks. Leanne says she uses her art to tell stories and to connect the observer with the land they stand on, highlighting their shared role in caring for Country as well as conveying the intrinsic spiritual connection Aboriginal people have with the land (L. Tobin, 2017, personal communication). Jacinta describes herself a language teacher and musician and songwriter who believes that music is a wonderful form of education and life. She works with schools, universities, community and government using her music and her community worker background to educate all on Darug language, songs and local Darug culture (J. Tobin, 2017, personal communication).

\section{Songlines: A learning story}

A long time ago, I was Nunggarayi, initiated into ceremony by Pintubi Luritja women in the Great Sandy Desert. There are no words, only body sensations of gritty ochre paint on kangaroo fat skin, visceral chanting of voices rising up through red earth to deep within our bodies, stomping, hip swaying movement to rhythm of clapsticks. A liminal space opens up that has never left me, searching for songlines that sing the wellbeing of Country with many Aboriginal collaborators. I am always and still the learner: understanding that I will never know the complexity of relationship with Country, but deeply committed to continuing the learning that is always so generously offered.

\section{Songlines as walking trails of ancestral creators}

I learn that an Aboriginal story incorporates song, music, dance, body painting and performance, all intersecting powerfully in a particular place through ceremony.

I learn that a songline is a walking trail that links story events in the path that the creation ancestors followed as they lived out their daily lives: walking through country, collecting food, living out the events that are marked forever in the landscape. At each of these special places a song is sung, and the songs are connected in the songline of the linking trails. It is along these linking trails that people walked to ceremony, making connections across country and beyond. 
In Gumbaynggirr country, I learn that the stars guide the way, represented in the placement of stones on the high peaks: stones that follow the diamond constellation of the stars of the Southern Cross. The pattern of stars of the Southern Cross is also Birrugan, the creation hero, whose actions created the walking trails, the line of story and of song.

Aboriginal artists teach me that contemporary Australian Aboriginal art draws from the intersection of these forms in ceremony and Country. Every knowledge framework, discipline, and artistic modality has its own forms and genres of place stories. There are no words in the liminal time and space to tell the changing story of Country. The always unfinished business of singing the Country recreates the death of the old and the coming of the new, in the cyclical returns of life.

Walking with Uncle Martin Ballangarry, I learn that walking trails are dynamic interactions between people and place. Places always have their histories, and the changing events that were significant in those histories are remembered in particular places as we walk. Everything signals other larger stories and connections; all is code for another series of stories, just like the epic Birrugan storyline. The storyline changes as the travel through country changes when, further on down the trail, we begin to map the water tracks that cross the river.

I learn that when language, story and country are reconnected, storylines become songlines again, and Country can once again be sung into (well)being.

\section{Walking the singing painting river's songlines}

I walk the Nepean Trail that traverses the riverlands from my home at Emu Green to Yarramundi in the mode of walking-with (Leanne and Jacinta) alone. I borrow from feminist geographer Juanita Sundberg's (Sundberg, 2014, as cited in Springgay \& Truman, 2018) strategy for walking as decolonizing research, that enacts situated and contingent ontologies between land, peoples, and nonhuman others. Drawing on examples from activist Indigenous peoples of Canadian and Mexican Zapatista movements, who articulate their practice as 'walking-with,' Sundberg says you can walk-with alone by being explicit about political positions and situated knowledges. Walking-with demands that we forgo universal claims about how humans and non-humans experience walking, and consider more-than-human ethics and politics of the material intra-actions of walking (Springgay \& Truman, 2018).

Through walking the singing painting river, my body moves through Country, learning to know its terrain: its air, water, minutiae of flora, and insect and bird life. The walking is so arduous that words are dispossessed of their power and the body enters into a meditative state of images, sounds, rhythms and movement. I write on my return, from photos, videos and images that stay with me in my bodymind.

\section{Walk 1: Walking in ochre 22/05/17}

Walking in ochre is meditation, movement and terrain: rough stony ground from decomposing sandstone, massive ups and downs, high up onto stony ridge with vast rocky outcrops of apple green lichen, lace patterned granite, hard and unyielding as stone, then winding down into deep hollows where waterways have formed gullies that tumble down the mountainside towards the river. River always alongside, sometimes beside, sometimes far below. Footfall is tricky on stony, slippery, sandy and steep ground, so what remains are the colours of ochre, imprinted in one's bodymind; deep clay coloured (and at times dark red), white, and yellow ochres make their own patterns along the road and across protruding rocks. A wave-like pattern of whites and delicate red is like its own artwork crafted on the rock of ages and I recall Leanne saying there are artworks in caves and rock shelters where Yellomundi meets the river at Shaws Creek. 
The walk is measured in creeks: five creeks from Fitzgerald Creek (wherever do they get these names) - the only one named on the Google Earth, the closest to home- to the halfway point. Cold air hovers in creek gullies, green moss on ever-shaded rocks, some flowing with still pools of water and, in the gullies, bellbirds chime symphonically. Birds call overhead: a melancholy crow, laughing kookaburras, carolling magpie, chattering rosellas, rarely visible, it is their song that accompanies the walk. And, on the ground, ants, everywhere, the sisters busy with whatever ants are busy with at home. I stop, fascinated, at one huge triangular shaped nest that colonises the entire dirt road to take photo and video, ants crawl up my legs, hastily brushing them off as I continue along the dirt, clay and rock trail. It is the colours of ochre that stay with me, producing a strong desire to make images, to create with all of these colours.

\section{Walk 11: Yellomundee body walk 25/06/17}

This walk is a sense of expansion into air: light space colour, deep blue of sky, serendipity of shadows on little creek crossing, water running through shadow of my body. It's all about body today. Video captures water rushing white bubbles through the shadow of my body, a body of water. I so want to get into this clear clean cold water but not today. Victorious arrival at halfway point, signature tree, large old river red gum, a place to sit and eat, place of home. Walking, walking and walking, body returns again, powerfully as I remove the last layer of light cotton singlet, feeling air on skin, warmth of sun, then cool cool in shade as damp cold air of creeks caresses skin. Back in my body. It's about embodied walking, the Yarramundi story. Leanne and Jacinta's Yarramundi songline, a walking trail of sound, music, colour, pattern, in the singing painting river's creations. I want to paint by soaking ironbark as Treahna taught me, but how to remove the tough tough bark, even loose bits won't break off. Charcoal from a burnt tree will do instead.

\section{Walking in deep time: images after the writing}

Revisiting this writing, composed immediately after the long walk, calls up a desire so strong that I return to the collection of photos and videos taken on the walk and download them from the iPhoto collection, curious to see what I would find. I export them and insert them into a word document and attempt to print them in colour. To save paper I juxtapose them on two pages. But alas, one prints as a full A4 colour image and I am blown away by its power. I select 10 to print in full and dwell in their aesthetic beauty. When I dwell in them in this way I realise that the artworks I so desired to make on the walk are already created by the singing painting river. They are their own creation story and songline, leading me along search trails to unexpected worlds.

\section{Sandstone: Dwelling in Gondwana.}

The first image is delicate wave patterns of pale grey, light and dark gold, and brown rising up in folds on sandstone, its lithic bulk contrasted with filaments of finest green grass. I learn the sandstone's creation storyline.

A long time ago (wugulgudji gurugal), Australia was part of the great Gondwana land linked with Antarctica, New Zealand and South America. The ripple marks on Hawkesbury Sandstone tell the story of the ancient river that brought the grains of sand from rocks formed between 500 and 700 million years ago far to the south. Australia's separation from Antarctica began about 97 million years ago, with initial seafloor spreading, substantial volcanic activity, and marine incursion into the southeast. Hawkesbury Sandstone was formed from sands that came from Antarctica about 200 million years ago, carried by a vast river system. Over millions of years these sands were consolidated into sandstone up to 50 metres 
thick. It forms the bedrock for much of the Sydney region, its durable quality the reason many Aboriginal rock carvings still exist today (L. Tobin, 2017, personal communication).

\section{Ochre: the ancient singing painting river}

Three photographs of ochre patterns are exquisite artworks of their own making: all from the track beneath my walking feet. The first is deep orange-gold, mottled with deeper red in delicate patterns; scatters of stone and rock erupt from the deep orange surface in lighter and darker colours, casting their own small shadows. In the second, an erupting fold of multicoloured rock tumbles down the steep track against a multi-coloured substrate of sand, stones and fine leaves. In the third, a close up of the tumbling rock reveals intricate lines and colours - mauve, brown, red, orange white and grey — scored across and through with fine lines in a chaos of interwoven patterns. The ochre images evoke the long-ago story of the singing painting river.

Ochre is the earliest known art material. It is a clay earth pigment, a mixture of ferric oxide and varying amounts of clay and sand, derived from the ancient clays that formed the bed rock of sandstone. It ranges in colour from yellow to deep orange or brown, with red ochre containing larger amounts of hematite or dehydrated iron oxide. Ochre is integral to Aboriginal Dreamtime legends, stories of creation and traditional laws of Aboriginal people throughout Australia. It sets down the Dreaming (Gunyalungalung in Dharug language), the Creation time for the Aboriginal People, which provides their identity and link to the land. Symbols painted in ochre on rock offer the first evidence of Aboriginal ethos, or philosophy, dating back more than 20,000 years, a thousand generations of people living in this land.

\section{Bodies of water}

There are three images of water from its tumbling journey down steep clefts in the sandstone mountainside, often ending in still cold pools. One image shows a stream cascading down the clefts in the mountainside, tumbling over a chaos of rocks, big rocks covered with bright green moss, small rocks tumbled into big ones, rocks visible under clear pools. Bubbles of white froth foam up as water rushes towards its river shaping its way through ancient sandstone.

Another shows water making art with my body, as my body's shadow is captured within its cold flow. The stream paints this transcorporeal body of water, the shadow image of my body, unexpectedly appearing within the cascading stream. Water flows through me and of me, this body that is seventy percent water. My head is decked with bright green ferns, leaning towards the water beside a huge boulder delicately etched with pale green lichen lace. Trails of white bubbles flow in and through belly and, at the feet, tiny green vestiges of plants stranded on water-strewn pathway.

A third water photograph is of a deep still pool with reflected images of blue sky and faint tiny white fluff clouds visible through tall trees, their trunks, leaves and branches reflected against a bed rock of pale green sandstone. The pool is a creation of the upside-down world of the Antipodes. It has captured sky County in the blue with its puff, the white clouds and the tall trees that reach up into the sky. It is the great storyline of Country as multidimensional.

There is sea country, land country and sky country:

Look, among the boughs. Those stars are men.

There's Ngintu, with his dogs, who guards the skins

of Everlasting Water in the sky.

And there's the Crow-man, carrying on his back 


\section{the wounded Hawk-man.}

There's the serpent, Thurroo, glistening in the leaves.

There's Kapeetah, the Moon-man, sitting in his mia-mia. (Rose, 1996, p.9).

All this made by the alchemy of water, a storyline that began in deep time when a monocline rose up from the otherwise flat Cumberland Plain of the Sydney Basin. The monocline is a sloping bend that raises the sandstone high above where it is expected to be seen. Over millions of years streams eroded deep gorges and cliff faces back into the uplifted block on the coastal side of the divide. Their creation story tells of the relationship between the lithic materiality of rock and stone, and the powerful gentle fluidity of ever-moving water that flows from its source high in the ridges on its travels to the ever-present river below.

\section{Ancient plants: Macrozamia and Eucalypt}

An image of Macrozamia, and one of a tall stately eucalypt, recall the creation songline of plants in this ancient land.

The Macrozamia appears as an image of a strange green-shelled fruit, its outer layer a bright aqua green triangle shaped husk with a long lime green spike protruding from its shell, which covers a brilliant red fruit. It lies abandoned among other discarded pieces of bright red on stony ground, grainy grey sand with stones and rocks of all shapes colours and sizes, sharp light grey, dark grey, palest of yellow ochre, even a deep purple umber shade. Stone and plant together. Puzzled, I wondered until I remember the ancient Macrozamia fruit excavated in an archaeological dig in the Warrumbungles, where Aboriginal people leached out the toxins from the cycads to make them edible.

Australian cycads coexisted with megafauna marsupials, such as Diprotodon, and herbivorous flightless birds, such as Genyornis, which are important dispersal agents for plants like Macrozamia. With their megafaunal means of dispersal gone, new storylines are emerging in a recent study, which found that feeding activity on the non-toxic green outer shell was intensive, but the red bare seed remains were discarded where they had been found. The brushtail possum was the only animal observed, most likely the source of discarded red fruits of macrozamia so strangely decorating the grainy grey road (Terry et al., 2005).

\section{One lone eucalypt tree}

A tall, tall tree reaches upwards to the sky, ragged branches radiating out like arms decked with fine eucalypt leaves. The artwork is in the trunk, a display of gorgeous colours, twisting diamond patterns, pale greeny grey, dark brown, light pinky gold ochre, reaching to the top of its tall trunk. At the base of the trunk, a mound of discarded sticks and leaves, a perfect camp, a halfway place to stop and rest after arduous up and downs of this long walk. It is Eucalyptus teretecornis, the river red gum that colonises the riverlands, its creation storyline as old as Gondwana itself.

The eucalypts have been present on the planet for about 65 million years. They are the iconic plant taxon in Australian vegetation today. Recent research suggests that the origin was close to the Cretaceous-Paleogene boundary in an area with high natural fire frequency. Adapted to fire, the Eucalypts have influenced the fire ecology of the Australian landscape more than any other plant group and are closely associated with the coming of the first humans, 40000 to 60000 years ago. The eucalypt's ongoing creation storyline intimately entangled with the original humans in this land. 


\section{The ever-present river}

One final photograph, the ever-present river, visible only as patches of clear bright blue through thick stands of eucalypts, is taken from the home place at the base of the river red gum.

The Nepean River, created during the early cretaceous period of the Sydney basin, today forms the veins of Western Sydney, its many tributaries criss-crossing suburban landscapes.

During the time of early colonisation, waterways were the only means of transport. Between 1788 (shortly after the arrival of the First Fleet) and 1789, Governor Arthur Phillip led three expeditions to explore the Hawkesbury, reaching further and further along the river, each time searching for farmlands to feed the growing colony. In 1791, he led further expeditions and established that the Hawkesbury and Nepean were the same river (Karskens, 2010). This is the river that encircles Sydney today, the megacity enabled by its ancient presence.

\section{Section 2: Performing the Singing Painting River}

In October of 2017, Leanne, Jacinta and I performed the singing painting river at the Overseas Passenger Terminal, where cruise ships regularly dock. This place is now known as Circular Quay, before that as Sydney Cove, the location of the first settlement of the invaders. It has always been, and still is, Gadigal land of the people of the Eora nation.

Two images from historical documents illustrate the contrast between these two eras of history of the city of Sydney. The first is a 1788 painting of the bay that is now Circular Quay, with two tiny sailing ships, signalling the arrival of the first fleet. The small inlet of water is surrounded by a low rocky shoreline, the ever-present eucalypt trees filling the landscape's background. In between, the trees are tents, the first shelters of the incoming migrants. Some of the shacks have fences, a sign of the enclosure of land to come, and a large union jack flag looms on one side, announcing the settlers' intentions of claiming this land. The year 1788 is described as a fatal turning point where black 'prehistory' is neatly sheared off so that the white history of city-making can begin (Karskens, 2010):

The ships sail into the grander heads of Port Jackson, the 'natives' shout at them from the shores, the scenery taking their breath away. The settlers land, raise the British flag and begin busily clearing and erecting the tents which looked pretty nestled among the great trees. (p. 61)

The second image shows a massive cruise ship having disgorged its 4000 passengers, disembarking briefly from their luxury cruise for a quick visit to this popular landing spot. They arrive via the overseas passenger terminal hidden behind its massive bulk. In the background, the entire skyline is filled with high-rise buildings, not a tree anywhere in sight.

This is the site of our invited public pedagogy performance of the singing painting river in a session called 'Connection to Country' at the Australian Institute of Landscape Architects' International Conference, the 3rd City. The performance aimed to take attendees "beyond post-industrial urbanisation to ask what is necessary and what is possible for future cities, their people, their ecologies, their territories and spaces" (Somerville, Tobin \& Tobin, 2017, n.p.).

The performance was composed of three songs performed by Jacinta and Leanne, interspersed with a brief oral presentation from me. Throughout our performance, 73 of Leanne's artworks were projected onto a rolling screen for the audience of 700 national and international visitors. The lyrics of the three songs, an extract of the interspersed oral text, and one of the paintings are presented below: 


\title{
The paintings
}

One of the 73 paintings produced as wall-sized rolling images in the overseas passenger terminal.

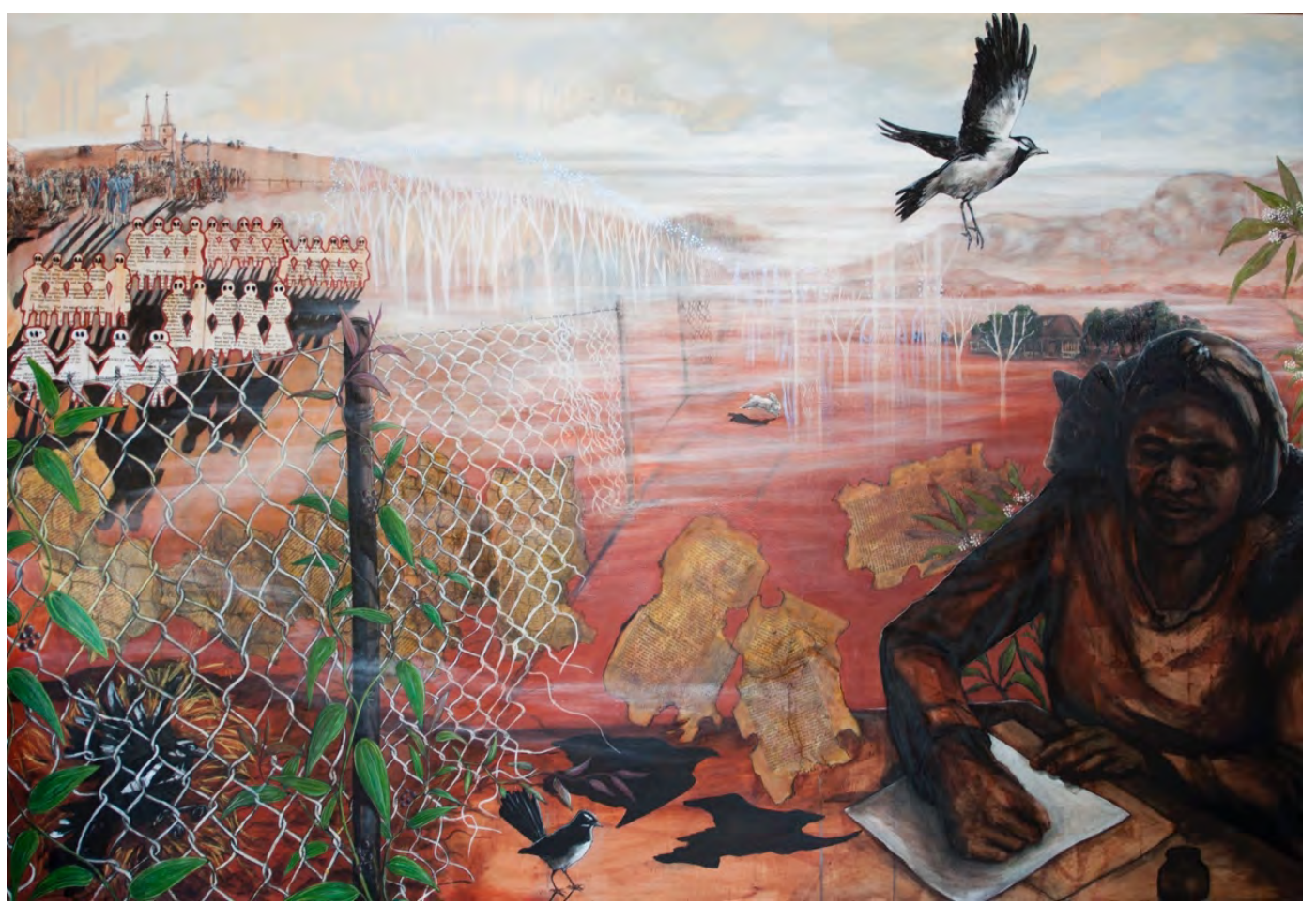

Figure 1: The Humble Petitioner, 2013. Artist: Leanne Tobin.

Maria Lock (tribal name Bolongaia) was the first Aboriginal woman to be awarded a land grant. The painting shows Maria writing her numerous letters to the governor. She would sign these letters 'your humble petitioner.' The possum on her shoulder is a collective Darug totem, the rabbit in the background alludes to the English. The cyclone fence is like a time portal linking the past with the present day. The peewee flying overhead and the willy wagtail jumping from post to post is a reminder of the freedom this land portion represented to those who came to live there after being removed from their original homelands.

\section{Song lyrics: Yarramundi}

\author{
Yarramundi used to \\ live at peace in this land \\ around the Hawkesbury he roamed \\ this old place he called home \\ and his songlines are still hummin' on \\ Yaarramundi \\ guess what \\ the colours nearly gone \\ a whole heap are dead \\ and your family are wed \\ but your bloodline \\ you are still livin' on \\ Yaaaaaaarramundi.
}


They poisoned the river I'm sorry

the times are all changed

I wish we could take

some responsibility

cos Yarramundi I never dreamt

it would be this extreme

cos people are tryin' to tell me

I need insurance and diamond riiiiings

Yaaaaaaarramundi

yeah, we're hummin on and livin' on and hummin on and livin' on

Yaaaaaaarramundi.

Cos people had small pox but Yarramundi knew

he knew the ancient ways

the secrets are dead we've gotta find them in our head or Yarramundi

please make a way

did you understand that energy did you,

did you use your heart with your brain

you didn't need technology or perplexity

and your pain yes it still remains

Yaaaaaaarramundi

Yeah, we're hummin' on and livin' on and hummin' on and livin' on

and hummin' on and

Yaaaaaaarramundi

I tried to walk in your shoes but your shoes

your shoes had too many thorns

because the farmers have got your land now

and your walking tracks no longer worn

but Yaarramundi you used to live at peace in this land

around the Hawkesbury you roamed this old place you called home

and his bloodlines are still livin' on Yaaaaaarramundi

yeah, we're hummin' on and livin' on and hummin' on and livin' on

and hummin' on and

Yaaaaaaarramundi.

(J. Tobin, 2017c).

\section{Extract from intervening text}

In the beginning all was Mulgury. Only creative power and intent. Through the intent and power of our Creator, Mulgury reproduces into form to carve the beings and shapes of the world where the water meets the sky and earth sings the world to life. The pattern of life is Mulgury and Mulgury is traced in the Niddrie [the framework of the ancient laws within Niddeerie]. Every tracing, every rock, tree, plant, landform, the water, fish, reptile, bird, animal and Mudri is in the sacred relationship, through Niddeerie. The pattern, shape and form of Mulgury is life, and all is a continuing tracing of Mulgury (Ticalarnabrewillaring, 1961, translated by Immiboagurramilbun in Somerville, 2013). 


\section{Song lyrics: The song sings on}

They've cleared all the trees

All but a few, once a woodland and plains,

Now suburbs and drains

The creek hidden from view.

But the song sings on

Beneath the culverts and the streets

The song sings on ...

Echoes from past gone

Connected and proud

The Darug breathed one with the land and its song

Its mother, its child

But still the song sings on

Waianamatta Mother Creek

The song sings on...

The Cumberland Plains hides secrets untold

Sit listen and learn

To the call of the Earth

Her wisdom so old!

So still the song sings on

Its needs denied for so long

The song sings on...

Now threatened and tired,

The waters so slow

Sing a watery dirge, strangled, submerged

The life gone from its flow

So, the song sings on

Hear its voice beneath your feet

The song sings on...

Now is the time, the woodland can't wait

To right the old wrong

And strengthen the song

Before it's too late.

The song sings on ....

Beneath culverts and the streets

The song sings on ...

And still the song sings on

Wainamatta, Mother Creek...

The song sings on.

(J. Tobin, 2017a). 


\section{Extract from oral presentation}

The Nepean River is the basis of an urban ecology passing through increasingly dense sites of urban agglomeration. Fish and other aquatic creatures, birds, reptiles, insects, mammals, plants, all living things can only thrive in the ecologies of these connections. Every day on the Nepean River at Emu Green is a new day; swans have come and gone with the passage of winter into Spring, red browed finches twitter all round, a bower bird exhibits its ever changing collection of blue objects to attract his harem, tiny silver fish disturb the still surface of the river as they jump for insects, eastern water dragon lizards become territorial, a dark swamp wallaby passes by, wattles come into bloom, in an endless proliferation of life in this urban commons. I wonder, how can we relearn this place as a relation of caring for Country?

\section{Song lyrics: Wirrawawee}

Wirrawee booboowhoo wirrawee booboowhoo yaaana nyiindi yaaana janawee

Aboriginal women strong

Aboriginal women strong

Walk with you walk with me

Janawee.

Wirrawee booboowhoo wirrawee booboowhoo yaaana nyiiindi yaaana janawee

Wirrawee booboowhoo wirrawee booboowhoo yaaana nyiindi yaaana janawee

Aboriginal women strong

Aboriginal women strong

Walk with you walk with me

Janawee.

Wirrawee booboowhoo wirrawee booboowhoo

Yaaana nyiindi yaaana nyiindi Janawee.

(J. Tobin, 2017b).

\section{Transcorporeal Bodies Dispersed in Deep Time, Space and Materiality}

In the first section of this paper I walk-with (Leanne and Jacinta) alone, following Sundberg's (2014) strategy of walking-with as decolonizing research that enacts situated and contingent ontologies between land, peoples and nonhuman others. I walk the Nepean Trail that links my part of the river at Emu Green to Yarramundi, symbolically connecting my present with Leanne and Jacinta's Darug past through their great, great, great grandmother, and daughter of Yarramundi. I re-imagine this walk as a songline through a lifetime of learning the walking trails of creation stories with Aboriginal peoples in this land. In this walk I become transcorporeal, re-embodied with air, light, sound and the ground beneath my feet. This ground is ever present in the rocky, slippy, bumpy up and downs of the long walking trail sculptured from deep time by water's fluid power flowing through rock over millennia in its inevitable journey to the river.

The walk generates an inescapable desire to create from its colours, shapes and stories, which etched the ancient land into my bodymind. This emerges into a process of representation when I mistakenly make a full-page colour print of one of the images made during the walk and recognise the singing painting river's work of art. I select some of these iconic images, print them all in full-page colour, and let them lead me where they will, following 
Haraway's representation of Despret's curious practice. Curious practice enables a thinking in attunement with the walk in all its multiple dimensions, including the new knowledge of deep time that is called up by the images. This new knowledge is expressed in words created from the materiality of the images, where matter and meaning emerge simultaneously in the ongoing intra-activity of the world's becoming (Barad, 2003).

Though the images I walk in the deep time of Gondwana land, the land where time began, as the Australian continent separated from Antarctica and the earliest bedrock of Sydney sandstone was formed. The time when the ancient clays became the ochres of the first paints of the world. The time when the waters created deep gullies as they flowed down through the sandstone of the great monocline that rose up from the flat Cumberland plain, forever seeking their home in the river. The time when ancient trees of the newly emerging continent, the eucalypts, came to be, shaped by fire and shaping the ecology of this land. The time when Aboriginal fire practices led to the extinction of the megafauna so they no longer dispersed the macrozamia seed scattered around my feet as I walk these old/new creation storylines. Walking in deep time produces anew the transcorporeal body, from sandstone, the waters, and plants, a body formed within the ancestral storylines of creation.

In the second section of the paper the walk is transposed to the literal site of first contact, always and still, the land of the Gadigal people, later named Sydney Cove, and now Circular Quay. The performance takes place in the overseas passenger terminal that regularly disgorges thousands of short-term tourists from luxury cruise ships, an ongoing site of visitors arriving from the sea. The only difference: these ones go home again. The performance does many things: it enacts the epistemological, ontological, and ethico-political of Springgay and Truman's (2018) walking methodologies; it creates a new songline of Country in this most symbolic of sites; and it evokes a powerful affective response in the audience to their experience of art, song, and story in this particular place.

The representative painting is an artefact of this deep time made from the red ochre of the ancient land. Spirit trees and the Old People are shadowy presences from the ancient past hovering in the background. The fences mark the dividing line between the sheared off past of Aboriginal prehistory, and the place of enclosure, foretold in the early makeshift fences constructed on the shores of Sydney Cove. The great, great, great grandmother Maria Lock is the pivotal point of deep time and now, as she writes her petitions in English to claim a portion of the land. She is heralded by peewee, willy wagtail, and the black crows that are also the shadows of disregarded petitions. Her totemic possum, nestled on her shoulder, protects her in the new creation storyline, presented through her continuing bloodline when Leanne and Jacinta perform at the place of the old, old story.

The song lyrics and their music evoke the beat and rhythm of ceremony, inviting the listeners to sing along with the chorus, incorporating these sounds into their bodies as they dwell in this place. They also tell the story of the plundering of their lands, the removal of trees, the burying of creeks under culverts and paving, and the unbearable losses of cultural knowledge and language. And yet, 'the song sings on' and the audience along with it, creating with us anew the songline of this place, an affective transformation that for many in the audience will never be forgotten.

Creative arts and curious practice evoked by this ancient land bring into being new songlines, lines of walking, and new ways of being and knowing into a world of increasing urbanization and loss. These songlines and walking trails are the invisible threads that link the human into an inseparable entanglement with the singing painting river. The movement from private meditative walk in deep time to the public performance of song, art and orality replicates the transition of us all in our world-making creative possibilities. 


\section{References}

Barad, K. (2003). Posthumanist performativity: Toward an understanding of how matter comes to matter. Journal of Women in Culture and Society, 28, 801-831. https://doi.org/10.1086/345321

Haraway, D. (2015). A Curious practice. Angelaki, 20(2), 5-14. https://doi.org/10.1080/0969725X.2015.1039817

Karskens, G. (2010). The colony: A history of early Sydney. Crows Nest, Australia: Allen and Unwin.

Rose, D. B. (1996). Nourishing terrains: Australian Aboriginal views of landscape and wilderness. Canberra, Australia: Australian Heritage Commission.

Somerville, M. (2013). Water in a dry land: Place-learning through art and story. Innovative Ethnography Series. London and New York: Routledge.

Somerville, M. \& Power, K, curators (2016). In K. Power \& S. Powell (Eds.), Meeting of the Waters [exhibition catalogue]. Penrith, Australia: Summer Institute of the Antipodes. Retrieved August $4^{\text {th }}, 2019$ from https://www.researchgate.net/publication/319059368 Meeting of the Waters Aborigi nal Artworks Summer Institute of the Antipodes

Somerville, M., Tobin, L. \& Tobin, J. (2017). Connection to Country. Plenary presentation, performed at Australian Institute of Landscape Architects (AILA) International Conference. Sydney: Australia.

Springgay, S. \& Truman, S. E. (2018). Walking methodologies in a more-than-human world: WalkingLab. New York, NY: Routledge.

Sundberg, J. (2014). Decolonizing posthuman geographies. Cultural Geographies, 21(1), 33-47. https://doi.org/10.1177\%2F1474474013486067

Terry, I., Walter, G. H., Donaldson, J. S., Snow, E., Forster, P., \& Machin, P. J. (2005). Pollination of Australian macrozamia cycads (zamiaceae): Effectiveness and behavior of specialist vectors in a dependent mutualism. American Journal of Botany 92(6): 931-940. 2005. https://doi.org/10.3732/ajb.92.6.931

Tobin, J. (2017a). The song sings on. [Audio file] Retrieved from https://www.jacintatobin.com.au

Tobin, J. (2017b) Wirrawee. [Audio file] Retrieved from https://www.jacintatobin.com.au

Tobin, J. (2017c). Yarramundi [Audio file] Retrieved from https://www.jacintatobin.com.au

Tobin, L. (2013). The Humble Petitioner [Painting with ochre, collage, charcoal and acrylic]. Sydney, Australia: Australian Institute of Landscape Architects (AILA) International Conference.

Margaret Somerville is a professor of Education at Western Sydney University. She is interested in alternative and creative approaches to research and writing for planetary wellbeing. She has many collaborations including with Aboriginal communities and their knowledge holders since her initiation by Pintubi Luritja women in the Great Sandy Desert. 
Leanne Tobin is descended from the Boorooberongal and Wumali clans of the Darug people. Leanne uses her art to tell local stories and to evoke an environmental conscience and respect towards the land and its original people while also conveying the intrinsic spiritual connection Aboriginal people have with the land.

Jacinta Tobin is a singer, songwriter, language teacher, and Darug descendent of the Aboriginal people of the Greater Sydney Region. She works with schools, universities, community and government events using her music and community worker qualifications and background to educate all on Darug language, songs and local Darug culture.

\footnotetext{
${ }^{\text {i }}$ Aboriginal peoples in Australia generally reject the term Indigenous, preferring either Aboriginal where it references a shared group culture Australia-wide, or the specific language group name, such as Darug, in relation to specific identifications. The Aboriginal collaborators on this project prefer the term Aboriginal as is evident from their song lyrics. The term Indigenous is used in the title to denote a more generic term and is my preferred term in this context.
} 